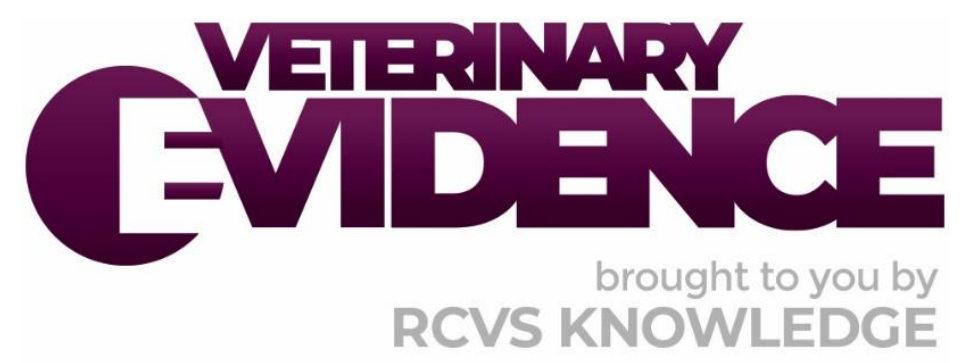

\title{
An evaluation of the use of ronidazole for the treatment of Tritrichomonas foetus in cats
}

\author{
A Knowledge Summary by
}

Genever Morgan BSc (Hons) BVetMed (Hons) MRCVS ${ }^{1^{*}}$

\footnotetext{
${ }^{1}$ Royal Veterinary College, 4 Royal College Street, London, NW1 OTU

* Corresponding Author (genevermorgan1987@gmail.com)
}

ISSN: 2396-9776

Published: 04 Dec 2019

in: Vol 4, Issue 4

DOI: 10.18849/VE.V4I4.263

Reviewed by: Katherine Briscoe (BVSc (Hons I), MVetStud, FANZCVS) and Nicolette Joosting (BSc (Hons),

Next Review Date: 03 Mar 2021 


\section{KNOWLEDGE SUMMARY}

\section{PICO question}

In cats infected with Tritrichomonas foetus, does treatment with oral ronidazole compared to an alternative antiprotozoal treatment or placebo result in successful resolution of clinical signs and eradication of disease?

\section{Clinical bottom line}

Ronidazole use appears to be efficacious in eradicating infection with Tritrichomonas foetus and resolving diarrhoea associated with infection. A dose range of 30-50 mg/ $/ \mathrm{kg} 12-24$ hourly has been suggested, with evidence suggesting that a dose of $30 \mathrm{mg} / \mathrm{kg} 24$ hourly for 14 days may be effective. However, some cats may require higher doses and some may not respond to treatment, and relapse may occur during a protracted period following completion of the treatment course. Neurological side effects appear to be uncommon but may occur with doses of $30 \mathrm{mg} / \mathrm{kg}$ and above.

A total of six studies are reviewed: Three randomised, controlled studies, one cohort study and two case series (one retrospective). Findings indicate efficacy of ronidazole treatment in eradicating infection and resolving diarrhoea, however many studies involved small sample sizes and limited follow-up. Therefore, evidence to support the use of ronidazole in Tritrichomonas foetus infected cats remains relatively limited.

\section{Clinical Scenario}

Tritrichomonas foetus is one of the most common causes of infectious colitis in cats. Remission from the diarrhoea associated with $T$. foetus infection may occur with time, however persistence of infection is common. This is particularly pertinent in cattery and shelter populations in which $T$. foetus infection is widespread. Ronidazole is currently the only drug with demonstrated efficacy against $T$. foetus, however it has a narrow safety margin and its use is currently off-license in the UK (Gookin et al. 2017).

\section{The evidence}

There is a small body of in vivo evidence for the treatment of cats infected with Tritrichomonas foetus using ronidazole, and of that evidence only half of the relevant papers are randomised, controlled, blinded studies. Therefore, the strength of the evidence is relatively low. A significant proportion of the evidence is from case series or cohort studies, where bias may be inherently introduced from case selection, the lack of blinding, no presence of a control/comparator and loss of patients to follow-up.

Most studies identified had a small sample size, with a limited follow up period in many.

There are three randomised, controlled studies examining the efficacy of ronidazole for treatment of $T$. foetus infection compared to placebo, all utilising different doses $(10-50 \mathrm{mg} / \mathrm{kg})$ and different dosing schedules (1224 hourly). 


\begin{tabular}{|c|c|}
\hline \multicolumn{2}{|l|}{ Grellet et al. (2017) } \\
\hline Population: & Cats naturally infected with $T$. foetus in French catteries \\
\hline Sample size: & 47 cats \\
\hline Intervention details: & $\begin{array}{l}\text { - Pharmacokinetics of ronidazole determined in vitro prior to the } \\
\text { clinical study being undertaken. } \\
\text { Existing infection with } T \text {. foetus detected via polymerase chain } \\
\text { reaction }(P C R) \text { undertaken on rectal swab sample. } \\
\text { - Confirmed infected cats randomly allocated into two groups: } \\
\text { placebo }(n=22) \text { or treatment }(n=25) \text {. } \\
\text { - Treatment group received ronidazole at } 30 \mathrm{mg} / \mathrm{kg} \text { once daily } \\
\text { for } 14 \text { days in guar gum coated capsule formulation, placebo } \\
\text { received capsule without ronidazole. }\end{array}$ \\
\hline Study design: & Randomised, controlled, double-blinded study \\
\hline Outcome studied: & $\begin{array}{l}\text { Repeat rectal swab undertaken after } 14 \text { days treatment, repeat } \\
\text { PCR undertaken. } \\
\text { Cats deemed still infected if PCR detected T. foetus presence } \\
\text { (objective assessment). } \\
\text { - Clinical examination undertaken and presence of adverse } \\
\text { effects recorded (subjective assessment). }\end{array}$ \\
\hline $\begin{array}{l}\text { Main findings: } \\
\text { (relevant to PICO question): }\end{array}$ & $\begin{array}{l}\text { Treatment group }-84 \%(21 / 25) T \text {. foetus not detected in cats } \\
\text { that received ronidazole. } \\
\text { - Placebo group }-18 \%(4 / 22) T \text {. foetus not detected in cats that } \\
\text { received placebo. } \\
\text { - Statistically significant difference between treatment and } \\
\text { placebo groups }(\mathrm{P}<0.001) \text {. } \\
\text { - No adverse drug reactions observed. }\end{array}$ \\
\hline Limitations: & $\begin{array}{l}\text { - Adverse effects of treatment are mentioned in the introduction, } \\
\text { and the authors have stated that any 'adverse effects' were } \\
\text { recorded; however, they do not describe which specific adverse } \\
\text { effects were being screened for in methods. } \\
\text { - Dose of ronidazole administered is alluded to in the } \\
\text { introduction, but there is no explanation in the method section } \\
\text { as to why the specific dose/dosing schedule used in this study } \\
\text { was selected. } \\
\text { Final PCR undertaken at end of } 14 \text { day treatment course, no } \\
\text { longer-term follow-up once treatment stopped. } \\
\text { 4/25 (16\%) of treated cats were still infected at the end of the } \\
\text { study, however cats appear to have not been kept separately } \\
\text { during the treatment phase and were in a multi-cat scenario. } \\
\text { Therefore it is difficult to know whether these cats were still } \\
\text { infected due to treatment failure, resistance of } T \text {. foetus to } \\
\text { ronidazole or reinfection. }\end{array}$ \\
\hline
\end{tabular}




\begin{tabular}{|c|c|}
\hline \multicolumn{2}{|l|}{ Gookin et al. (2006) } \\
\hline Population: & $\begin{array}{l}\text { An adult cat with naturally occurring } T \text {. foetus infection and } 10 \text { week } \\
\text { old, specific-pathogen free kittens }\end{array}$ \\
\hline Sample size: & $\begin{array}{l}\text { - } \quad \text { One adult cat with naturally acquired infection } \\
\text { - } 10 \text { specific-pathogen free kittens }\end{array}$ \\
\hline Intervention details: & $\begin{array}{l}\text { - Susceptibility of } T \text {. foetus to ronidazole, tinidazole and } \\
\text { metronidazole determined in vitro prior to clinical study. } \\
\text { Infection with T. foetus confirmed in adult cat via direct } \\
\text { microscopy, faecal culture and PCR on faecal sample. Organisms } \\
\text { obtained to use in in vitro susceptibility study. } \\
\text { - Adult cat treated with } 10 \mathrm{mg} / \mathrm{kg} \text { ronidazole q } 24 \text { hours for } 10 \\
\text { days. } \\
\text { - Specific-pathogen free kittens randomly split into two equal } \\
\text { groups (n=5). Health determined during initial } 3 \text { week } \\
\text { acclimatisation period via clinical examination, biochemistry, } \\
\text { haematology and urinalysis. Faeces examined for enteric } \\
\text { pathogens via faecal flotation, direct microscopy, microbial } \\
\text { culture, antigen testing for Giardia spp. and PCR for detection of } \\
\text { T. foetus ribonucleic acid (RNA) } \\
\text { Kittens experimentally infected via orogastric intubation with } T \text {. } \\
\text { foetus in specifically prepared medium containing approximately } \\
3 \times 10^{6} \text { live } T \text {. foetus. } \\
\text { Treatment initiated } 4 \text { weeks after experimentally induced } \\
\text { infection. Kittens received either ronidazole (10 mg/kg) or } \\
\text { dextrose (placebo) twice daily q } 12 \text { hours via colour coded gel } \\
\text { capsules for } 14 \text { days. }\end{array}$ \\
\hline Study design: & Randomised, controlled study (specific-pathogen free kittens) \\
\hline Outcome studied: & $\begin{array}{l}\text { PCR undertaken on faeces weekly for } 6 \text { weeks to determine } \\
\text { presence of } T \text {. foetus (objective). } \\
\text { Cats with residual } T \text {. foetus still present given treatment with } \\
\text { higher dose ronidazole } 30 \text { or } 50 \mathrm{mg} / \mathrm{kg} \mathrm{q} 12 \text { hours for } 14 \text { days. } \\
\text { Weekly PCR undertaken on faeces for minimum of } 20 \text { weeks. } \\
\text { - Presence of adverse effects (subjective). }\end{array}$ \\
\hline $\begin{array}{l}\text { Main findings: } \\
\text { (relevant to PICO question): }\end{array}$ & $\begin{array}{l}\text { - Adult cat treatment group: No trichomonads on faecal screen } \\
\text { after } 24 \text { hours treatment. Immediate improvement in faecal } \\
\text { consistency, normal after } 10 \text { day treatment course. } T \text {. foetus not } \\
\text { identified via PCR at day } 15 \text { or } 31 \text { after treatment. } \\
\text { - Adult cat day } 85 \text { post-treatment: Relapse of clinical signs and } \\
\text { repeat isolation of } T \text {. foetus, resolved with repeat treatment } \\
\text { using ronidazole at same dose and duration. No further isolation } \\
\text { of } T \text {. foetus up to day } 407 \text { after treatment. } \\
\text { Kitten treatment group: Resolution of } T \text {. foetus following } \\
\text { treatment, relapse of infection in all kittens in follow-up period } \\
\text { after completion of treatment (2-20 weeks). }\end{array}$ \\
\hline
\end{tabular}




\begin{tabular}{|c|c|}
\hline & $\begin{array}{l}\text { - Kitten placebo group: all remained positive. } \\
\text { either } 30 \text { or } 50 \mathrm{mg} / \mathrm{kg} \text { ronidazole q } 12 \text { hours for } 14 \text { days. } \\
\text { Resolution of infection documented. No relapse identified in } \\
\text { follow-up period of } 30 \text { and } 21-23 \text { weeks respectively. } \\
\text { No adverse events reported during or after treatment in all } \\
\text { groups. Subjectively softer faeces were reported in cats while } \\
\text { receiving } 50 \mathrm{mg} / \mathrm{kg} \text { ronidazole. }\end{array}$ \\
\hline Limitations: & $\begin{array}{l}\text { - Unclear why the single naturally infected cat was included in the } \\
\text { study. } \\
\text { - Small sample size of } 10 \text { specific-pathogen free kittens, no power } \\
\text { calculation included. } \\
\text { - Study not fully blinded as colour coded capsules used to } \\
\text { differentiate those containing ronidazole from placebo. } \\
\text { Unclear why a low dose of ronidazole was initially utilised, then } \\
\text { two different higher doses ( } 30 \mathrm{mg} / \mathrm{kg} \text { or } 50 \mathrm{mg} / \mathrm{kg} \text { ) were used } \\
\text { when relapse occurred or to treat infected kittens originally } \\
\text { administered with the placebo. }\end{array}$ \\
\hline
\end{tabular}

\begin{tabular}{|c|c|}
\hline \multicolumn{2}{|l|}{ Gookin et al. (2010) } \\
\hline Population: & Abyssinian cats in a cattery \\
\hline Sample size: & 11 cats \\
\hline Intervention details: & $\begin{array}{l}\text { - } 8 / 11 \text { cats in a single cattery with diarrhoea and positive } \\
\text { diagnosis of } T \text {. foetus on faecal culture. } \\
\text { - Treatment with } 35-45 \mathrm{mg} / \mathrm{kg} \text { ronidazole } \mathrm{q} 12 \text { hourly for } 14 \text { days } \\
\text { ( } 1-2 \text { courses). } \\
\text { - Repeat faecal cultures ( } 2-5 \text { cultures per cat). }\end{array}$ \\
\hline Study design: & Case series \\
\hline Outcome studied: & $\begin{array}{l}\text { - } \\
\text { - } \text { Resolution of diarrhoea (subjective) } \\
\text { - In vitro susceptibility to ronidazole in aerobic and anaerobic } \\
\text { conditions (objective). }\end{array}$ \\
\hline $\begin{array}{l}\text { Main findings: } \\
\text { (relevant to PICO question): }\end{array}$ & $\begin{array}{l}\text { - Treatment with one (seven cats) or two (one cat) courses of } \\
\text { ronidazole } 35-45 \mathrm{mg} / \mathrm{kg} \text { q } 12 \text { hourly for } 14 \text { days resulted in } \\
\text { repeatedly negative faecal cultures for } T \text {. foetus in six cats and } \\
\text { resolution of diarrhoea. } \\
\text { - } \text { Infection was still present in } 2 / 8 \text { cats. Repeat courses of } \\
\text { metronidazole ( } 20-32 \mathrm{mg} / \mathrm{kg} \text { q } 24 \text { hours, unknown duration), } \\
\text { tinidazole ( } 50 \mathrm{mg} / \mathrm{kg} \mathrm{q} 24 \text { hours for } 14 \text { days) and ronidazole ( } 35- \\
60 \mathrm{mg} / \mathrm{kg} \text { q } 12 \text { hours for } 14 \text { days) were administered to these } \\
\text { cats over the course of } 1 \text { year. } \\
\text { Multiple courses of metronidazole, tinidazole and ronidazole did } \\
\text { not clear } T \text {. foetus infection suggesting in vivo resistance. } \\
\text { After } 1 \text { year of treatment, infection was still not eradicated in } \\
2 / 8 \text { cats. Faeces from these two cats was collected and in vitro } \\
\text { susceptibility to ronidazole tested. }\end{array}$ \\
\hline
\end{tabular}




\begin{tabular}{|c|c|}
\hline & $\begin{array}{l}\text { - In vitro resistance of } T \text {. foetus to ronidazole demonstrated in } \\
\text { aerobic conditions. } \\
\text { - No weight loss, inappetence or neurological signs observed. One } \\
\text { cat vomited three times in first } 24 \text { hours of treatment although } \\
\text { unclear which drug was being administered at this point. }\end{array}$ \\
\hline Limitations: & $\begin{array}{l}\text { - In vivo part of study not controlled or blinded. } \\
\text { - Small sample size. } \\
\text { - Resistance of } T \text {. foetus to ronidazole in vivo assumed from non- } \\
\text { response to treatment, however small cohort examined ( } \mathrm{n}=2 \text { ). } \\
\text { Cats included in study were blanket treated with different drug } \\
\text { courses/combinations rather than a defined treatment regimen. } \\
\text { - Susceptibility of } T \text {. foetus to ronidazole in aerobic conditions } \\
\text { suggested in this study, however this was only demonstrated in } \\
\text { one cat. Further studies required to substantiate this claim. }\end{array}$ \\
\hline
\end{tabular}

\begin{tabular}{|c|c|}
\hline \multicolumn{2}{|l|}{ Koster et al. (2015) } \\
\hline Population: & $\begin{array}{l}\text { Medical records of domestic cats presented to two veterinary clinics } \\
\text { in Hong Kong over a } 5 \text { year period. } \\
\text { Only cases with complete medical record and confirmed } T \text {. foetus } \\
\text { diagnosis (history, clinical examination and details of diagnostic } \\
\text { testing) included. }\end{array}$ \\
\hline Sample size: & 29 cats \\
\hline Intervention details: & $\begin{array}{l}\text { - Diagnosis of } T \text {. foetus made by combination of faecal smear } \\
\text { microscopy and faecal PCR. } \\
\text { - All cats treated with } 30 \mathrm{mg} / \mathrm{kg} \text { ronidazole q } 24 \text { hourly for } 14 \\
\text { days. }\end{array}$ \\
\hline Study design: & Case series, retrospective \\
\hline Outcome studied: & $\begin{array}{l}\text { - } \quad \text { Signalment of affected cats (objective). } \\
\text { - } \quad \text { Presence of diarrhoea (subjective). } \\
\text { - } \text { sesponse to ronidazole treatment at recommended dosing } \\
\text { - Presence of co-infection with Giardia spp. (objective). }\end{array}$ \\
\hline $\begin{array}{l}\text { Main findings: } \\
\text { (relevant to PICO question): }\end{array}$ & $\begin{array}{l}\text { - } 25 / 29 \text { ( } 86 \%) \text { of cats were purebred, } 19 / 29 \text { (66\%) were male, } \\
\text { median age } 10 \text { months. } \\
\text { All } 29 \text { cats had diarrhea identified in the medical record. } 13 \text { had } \\
\text { large bowel diarrhoea, } 16 \text { had mixed small- and large-bowel } \\
\text { diarrhoea. } \\
\text { - } 24 / 29(83 \%) \text { cats responded to ronidazole treatment, with } \\
\text { resolution of clinical signs. } 5 / 29 \text { ( } 17 \%) \text { cats did not respond, two } \\
\text { of which were from multi-cat households. } \\
\text { - } 9 / 29(31 \%) \text { cats were co-infected with Giardia spp. }\end{array}$ \\
\hline Limitations: & $\begin{array}{l}\text { - Retrospective study of medical records, therefore lack of control } \\
\text { group and not, randomised or blinded. } \\
\text { - Bias in signalment may be present as owned cats presenting to }\end{array}$ \\
\hline
\end{tabular}




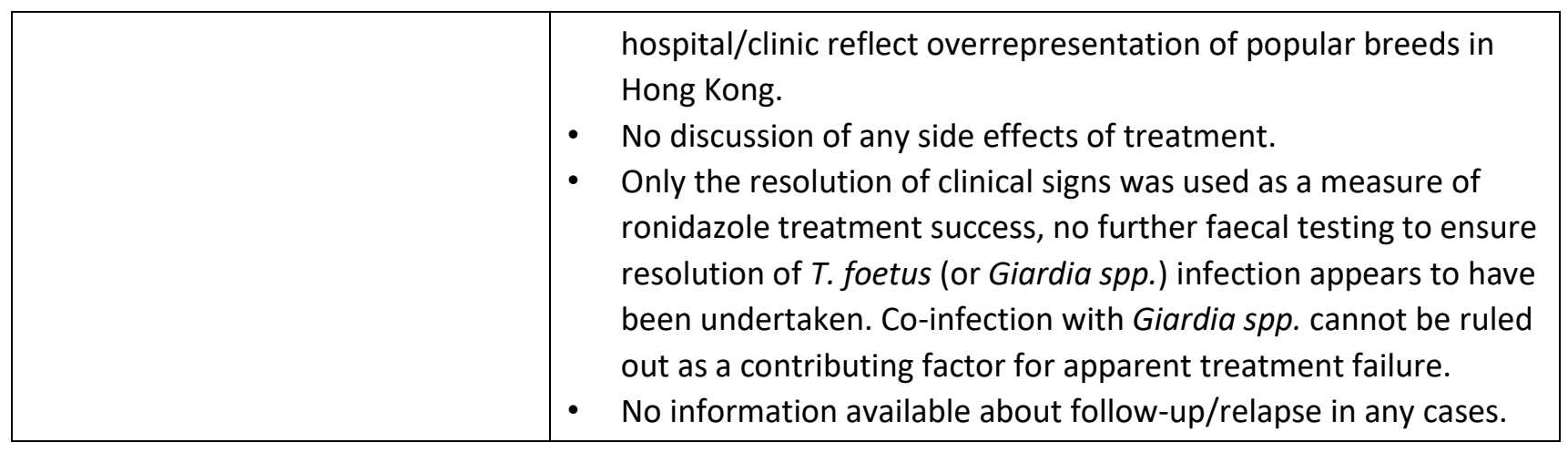

\begin{tabular}{|c|c|}
\hline \multicolumn{2}{|l|}{ Lim et al. (2012) } \\
\hline Population: & 5-7 month old Korean Domestic Short Hair kittens \\
\hline Sample size: & Six kittens \\
\hline Intervention details: & $\begin{array}{l}\text { - Kittens confirmed free of } T \text {. foetus via faecal smear, culture from } \\
\text { - } \text { Kittens divided into two groups ( } n=3 \text { ), sedated and administered } \\
\text { media containing } T \text {. foetus trophozoites via feeding tube. } \\
\text { - Infection with } T \text {. foetus confimed via faecal examination of } \\
\text { trophozoites by day } 20 \text { post inoculation. } \\
\text { - Treatment group ( } n=3 \text { ): } \\
\text { O Oral administration of } 50 \mathrm{mg} / \mathrm{kg} \text { ronidazole in gel capsules q } \\
12 \text { hourly for } 14 \text { days } \\
\text { Placebo group ( } n=3 \text { ): Empty gel capsule placebo from day } \\
30 \text { post inoculation. } \\
\text { - Faecal smear, culture from rectal swab and PCR undertaken once } \\
\text { weekly for following } 4 \text { weeks. }\end{array}$ \\
\hline Study design: & Randomised controlled, non-blinded study \\
\hline Outcome studied: & $\begin{array}{l}\text { - Presence of diarrhoea following experimental infection } \\
\text { (subjective). } \\
\text { - Presence of T. foetus in faeces during treatment period and } 4 \\
\text { week follow-up (objective). }\end{array}$ \\
\hline $\begin{array}{l}\text { Main findings: } \\
\text { (relevant to PICO question): }\end{array}$ & $\begin{array}{l}\text { - No diarrhoea was observed in any cat following experimental } \\
\text { infection. } \\
\text { - Treatment group: All cats negative for T. foetus during treatment } \\
\text { period and } 4 \text { week follow-up period. } \\
\text { - Placebo group: All cats remained positive for T. foetus } \\
\text { throughout the study. }\end{array}$ \\
\hline Limitations: & $\begin{array}{l}\text { - } \quad \text { Small sample size. } \\
\text { - } \quad \text { No discusing difficult to achieve as empty capsules used for placebo. } \\
\text { previous studies was used in this study. } \\
\text { - } \quad \text { No discussion of any side effects that may or may not have been } \\
\text { seen with higher dose of ronidazole administered. }\end{array}$ \\
\hline
\end{tabular}




\begin{tabular}{|l|l|}
\hline & $\begin{array}{l}\text { Short-term follow-up period of } 4 \text { weeks, treatment appears } \\
\text { effective during the immediate post-treatment period, however } \\
\text { it cannot be determined whether ronidazole administration at } \\
\text { this dose is effective at preventing relapse over longer periods. }\end{array}$ \\
\hline
\end{tabular}

\begin{tabular}{|c|c|}
\hline \multicolumn{2}{|l|}{ Reinert et al. (2016) } \\
\hline Population: & $\begin{array}{l}\text { Abyssinian cats. Two male, five female cats with intermittent large } \\
\text { bowel diarrhoea despite treatment with fenbendazole. }\end{array}$ \\
\hline Sample size: & Seven cats \\
\hline Intervention details: & $\begin{array}{l}\text { - } \quad \text { T. foetus diagnosed via faecal PCR. } \\
\text { - } \text { hourly for } 14 \text { days. } \\
\text { - Cats kept separately in isolation and given physical examinations } \\
\text { and neurological examinations daily. } \\
\text { - } \quad \text { Repeat PCR undertaken on faeces over period of } 345-800 \text { days. } \\
\text { - Two cats lost through euthanasia as result of other conditions. } \\
\text { Cats euthanised following } T \text {. foetus diagnosis but prior to starting } \\
\text { treatment with ronidazole. }\end{array}$ \\
\hline Study design: & Cohort study \\
\hline Outcome studied: & $\begin{array}{l}\text { - Presence of } T \text {. foetus in faeces via PCR in follow-up period } \\
\text { (objective). } \\
\text { - Presence of side effects of treatment (subjective). }\end{array}$ \\
\hline $\begin{array}{l}\text { Main findings: } \\
\text { (relevant to PICO question): }\end{array}$ & $\begin{array}{l}\text { - Neurological side effects seen in two cats, treatment paused for } \\
\text { one day then restarted. } \\
\text { - No evidence of } T \text {. foetus (via faecal PCR) in any cat during up to } \\
800 \text { day follow-up, infection deemed eliminated. } \\
\text { - } 2 / 7 \text { cats initially diagnosed with T. foetus lost to follow up due to } \\
\text { euthanasia. }\end{array}$ \\
\hline Limitations: & $\begin{array}{l}\text { - No discussion about presence/improvement of diarrhoea over } \\
\text { follow-up period. } \\
\text { - } \quad \text { No discussion as to why ronidazole dose chosen was used. } \\
\text { - } \quad \text { Cohort sample size. } \\
\end{array}$ \\
\hline
\end{tabular}

\section{Appraisal, application and reflection}

There are few papers examining the in vivo efficacy of oral ronidazole treatment in cats infected with Tritrichomonas foetus. Of these papers, half were randomised, controlled, blinded studies comparing the use of oral ronidazole with placebo, however the remaining half were case series or cohort studies. Therefore, there is a significant amount of lower quality evidence present. 
One major problem present in most of the papers is that a small sample size was utilised. Although many results were significant, this may mean that the results are not representative of a wider population and conclusions may not be robust.

Infection with $T$. foetus was induced experimentally via orogastric intubation in two of the randomised, controlled studies (Gookin et al. 2006 and Lim et al. 2012), therefore the results of these studies may not be truly reflective of naturally occurring infection.

There is significant variation in the treatment protocols described in the studies. All three randomised, controlled, blinded studies utilised different doses and dosing schedules of ronidazole. Grellet et al. (2017) used $30 \mathrm{mg} / \mathrm{kg}$ once daily for 14 days, Gookin et al. (2006) initially used $10 \mathrm{mg} / \mathrm{kg}$ twice daily for 14 days, then $30-50 \mathrm{mg} / \mathrm{kg}$ twice daily for 14 days and Lim et al. (2012) used $50 \mathrm{mg} / \mathrm{kg}$ twice daily for 14 days.

Both Grellet et al. (2017) and Lim et al. (2012) observed eradication of T. foetus in treated cats at the end of treatment after 14 days of treatment (determined via PCR on rectal swab), however clinical signs of diarrhoea were not examined and there was limited monitoring for recurrence following cessation of treatment. Gookin et al. (2006) observed that lower dose $(10 \mathrm{mg} / \mathrm{kg})$ ronidazole did initially resolve infection during the treatment period, however all kittens relapsed within 2-20 weeks and required further treatment with $30-50 \mathrm{mg} / \mathrm{kg}$ ronidazole twice daily, after which no relapse was observed in the following 21-30 weeks and diarrhoea resolved.

The use of 35-45 mg/kg ronidazole twice daily for 14 days was also demonstrated to eradicate $T$. foetus on faecal culture and resolve diarrhoea in six cats, with repeated negative culture on follow-up in a small case series by Gookin et al. (2010).

Koster et al. (2015) presented a retrospective case series also describing the use of $30 \mathrm{mg} / \mathrm{kg}$ ronidazole q 24 hours for 14 days in cats presented to a hospital environment with $T$. foetus confirmed via faecal smear microscopy and PCR. This dosing schedule was found to successfully resolve diarrhoea in 24/29 cats, however confirmation of resolution of infection via faecal PCR was not undertaken and there was no follow-up to determine whether relapse occurred.

The use of $30 \mathrm{mg} / \mathrm{kg}$ ronidazole q 24 hours for 14 days was also documented by Reinert et al. (2016) in a small cohort study and found to be successful in eradicating infection (demonstrated via faecal PCR) and preventing relapse up to 800 days following treatment completion. Presence of diarrhoea was not described. However, this was a small cohort study of five treated cats with no control or comparator group to substantiate the result.

A confounding factor for both the Koster et al. (2015) case series and Grellet et al. (2017) randomised, controlled study is that treated cats which continued to live in a multi-cat household environment were included. In both studies, a proportion of cats did not respond to treatment/remained infected, however it is impossible to know why treatment failure occurred as this could be a demonstration of resistance of $T$. foetus to ronidazole therapy, or simply reinfection.

Therefore, the use of $30 \mathrm{mg} / \mathrm{kg}$ ronidazole q 24 hours for 14 days may be a useful initial treatment regimen in eradicating infection with $T$. foetus and resolution of diarrhoea, with a successful result documented in the randomised, controlled study by Grellet et al. (2017) and supported by the cohort study by Reinert et al. (2016) and case series by Koster et al. (2015). However further case controlled, analytical studies should be undertaken to substantiate this. The case series and cohort studies are subject to bias and the result of the randomised, controlled study is complicated by the test and placebo cats not being housed separately during treatment, leading to possible reinfection. 
Ronidazole appeared to be superior in efficacy against $T$. foetus compared to metronidazole and tinidazole (Gookin et al. 2006 and Gookin et al. 2010) and was effective in eradicating infection in cats previously treated unsuccessfully with fenbendazole in the small cohort study by Reinert et al. (2016). However, two cats did not respond to repeated ronidazole administration in the case series by Gookin et al. (2010). Resistance in vivo was suggested, and in vitro resistance was demonstrated in aerobic conditions in one cat, although further studies on larger numbers of cats are required to validate this finding.

Ronidazole is suggested to have a narrow therapeutic range and neurological side effects are documented to occur with treatment (Gookin et al., 2017), however these were infrequently evidenced in this knowledge summary, with only Reinert et al. (2016) observing effects in 2 cats which resolved on pausing treatment. Lim et al. (2012) specifically described the use of high dose $50 \mathrm{mg} / \mathrm{kg}$ ronidazole 12 hourly for 14 days. This was found to be successful in eradicating infection on faecal analysis, however the presence of any neurological side effects was unfortunately not discussed. Gookin et al. (2006) also administered doses up to $50 \mathrm{mg} / \mathrm{kg}$ twice daily and no adverse effects were seen.

\section{Conclusions}

There is a small amount of good quality evidence for the use of ronidazole to treat cats with diarrhoea as a result of Tritrichomonas foetus infection, and a range of therapeutic protocols have been described. A dose of $30-50 \mathrm{mg} / \mathrm{kg}$ administered once to twice daily for 14 days appears to be successful in eradicating infection and may successfully prevent relapse of infection for up to 800 days, although the evidence for this is limited. Neurological side effects may be observed in cats treated with doses of $30 \mathrm{mg} / \mathrm{kg}$ and above. Resistance of $T$. foetus to ronidazole has been suggested (Gookin et al., 2010), however additional work is needed to substantiate this further.

The small body of evidence currently available would suggest that the use of ronidazole is efficacious in treating $T$. foetus in cats and does resolve the associated diarrhoea, supporting the use of ronidazole in clinical practice in cats with diarrhoea and T. foetus confirmed via PCR/faecal culture. Based on this, the use of ronidazole as an off-license medication is therefore justified in the absence of a licensed alternative. The studies by Grellet et al. (2017), Koster et al. (2015) and Reinert et al. (2016) all suggest that a dosing schedule of $30 \mathrm{mg} / \mathrm{kg}$ once daily for 14 days is successful in treating infection, therefore may be a useful initial regimen. Based on the evidence generated by the search strategy for this knowledge summary, twice daily dosing and doses of up to $50 \mathrm{mg} / \mathrm{kg}$ may be required to eradicate infection and appeared to be safely tolerated. However, the studies detailing twice daily dosing are relatively old. A study by LeVine et al. (2011) investigating the pharmacokinetics of both intravenous and oral administration of ronidazole to cats observed a prolonged half-life of 10.5 hours for ronidazole.

Therefore, due to concerns about ronidazole accumulation and increased risk of neurological side effects occurring, twice daily dosing is no longer recommended (LeVine et al., 2011 and LeVine et al., 2014).

Importantly it appears that some cats may not respond to treatment and relapse may occur in a protracted period post-treatment, therefore patients should be monitored for this occurring. 


\section{Methodology Section}

\begin{tabular}{|c|c|}
\hline \multicolumn{2}{|l|}{ Search Strategy } \\
\hline \multirow{3}{*}{$\begin{array}{r}\text { Databases searched and dates } \\
\text { covered: }\end{array}$} & CAB Abstracts via CAB Direct (1973-Week 8 2019) \\
\hline & PubMed via NCBI website (1946-Week 8 2019) \\
\hline & Scopus via Elsevier (1823-Week 8 2019) \\
\hline Search terms: & $\begin{array}{l}\text { (cat OR cats OR feline OR felis) AND Tritrichomonas(foetus OR fetus) } \\
\text { AND ronidazole AND (efficacy OR susceptibility) }\end{array}$ \\
\hline Dates searches performed: & 24/02/2019-3/3/2019 \\
\hline
\end{tabular}

\section{Exclusion / Inclusion Criteria}

Exclusion: Completely in vitro studies, review articles, studies not relevant to the PICO question, conference proceedings presenting overview or non-relevant information.

Inclusion: In vivo studies, studies with more than one animal, studies relevant to PICO question, studies including treatment with ronidazole plus placebo and/or alternative antiprotozoal drug.

\begin{tabular}{|c|c|c|c|c|c|c|}
\hline \multicolumn{7}{|c|}{ Search Outcome } \\
\hline Database & $\begin{array}{c}\text { Number } \\
\text { of } \\
\text { results }\end{array}$ & $\begin{array}{c}\text { Excluded - } \\
\text { Comment } \\
\text { letter }\end{array}$ & $\begin{array}{c}\text { Excluded - } \\
\text { single case } \\
\text { report }\end{array}$ & $\begin{array}{c}\text { Excluded - } \\
\text { irrelevant to } \\
\text { PICO }\end{array}$ & $\begin{array}{c}\text { Excluded - not } \\
\text { accessible }\end{array}$ & $\begin{array}{c}\text { Total } \\
\text { relevant } \\
\text { papers }\end{array}$ \\
\hline $\begin{array}{l}\text { CAB } \\
\text { Abstracts }\end{array}$ & 14 & 3 & 3 & 1 & 2 & 5 \\
\hline PubMed & 10 & 2 & 1 & 3 & 0 & 4 \\
\hline Scopus & 10 & 3 & 2 & 1 & 0 & 4 \\
\hline Total releva & ers w & duplicate & ed & & & 6 \\
\hline
\end{tabular}

\section{CONFLICT OF INTEREST}

The author declares no conflict of interest. 


\section{REFERENCES}

1. Grellet, A., Makhlouf, S.E., Desquilbet, L., Hovhannessian, F., Boogaerts, C., Dore, V., Anthony, M., Espana, B., Prouillac, C., Kirilov, P., Polack, B., \& Perrot, S. (2017). 'Efficacy of guar gum-based ronidazole capsules as a treatment for Tritrichomonas foetus infection in cats', Journal of Feline Medicine and Surgery, 19 (2), pp. 177-184. DOI: https://doi.org/10.1177/1098612X15621353

2. Gookin, J.L., Copple, C.N., Papich, M.G., Poore, M.F., Stauffer, S.H., Birkenheuer, A.J., Twedt, D.C., \& Levy, M.G. (2006). 'Efficacy of ronidazole for treatment of feline Tritrichomonas foetus infection', Journal of Veterinary Internal Medicine, 20 (3), pp. 536-543. DOI: https://doi.org/10.1111/i.1939-1676.2006.tb02893.x

3. Gookin, J.L., Stauffer, S.H., Dybas, D., \& Cannon, D.H. (2010). 'Documentation of in vivo and in vitro aerobic resistance of feline Tritrichomonas foetus isolates to ronidazole', Journal of Veterinary Internal Medicine, 24 (4), pp. 1003-1007. DOI: https://doi.org/10.1111/j.1939-1676.2010.0534.x

4. Gookin, J.L., Hanrahan, K., \& Levy, M.G. (2017). 'The conundrum of feline Trichomonosis', Journal of Feline Medicine and Surgery, 19 (3), pp. 261-274. DOI: https://doi.org/10.1177/1098612X17693499

5. Koster, L.S., Chow, C., \& ChaoQun, Y. (2015). 'Trichomonosis in cats with diarrhoea in Hong Kong, China, between 2009 and 2014', Journal of Feline Medicine and Surgery Open Reports, 1 (2), pp. 1-4 ref.28. DOI: https://doi.org/10.1177/2055116915623561

6. LeVine, D.N., Papich, M.G., Gookin, J.L. (2011). 'Ronidazole pharmacokinetics after intravenous and oral immediate-release capsule administration in healthy cats', Journal of Feline Medicine and Surgery, 13, pp. 244-250. DOI: https://doi.org/10.1016/i.jfms.2010.12.001

7. LeVine, D.N., Gookin, J.L., Papich, M.G., \& Davidson, G.S. (2014). 'Twice-daily dosing of RDZ no longer recommended for treatment of intestinal Tritrichomonas foetus infection', Journal of Feline Medicine and Surgery, 16 (2), pp. 198. DOI: https://doi.org/10.1177/1098612X13506430

8. Lim, S., Park, S.I., Ahn, K.S., Oh, D.S., \& Shin, S.S. (2012). 'Efficacy of ronidazole for treatment of cats experimentally infected with a Korean isolate of Tritrichomonas foetus', Korean Journal of Parasitology, 50 (2), pp. 161-164. DOI: https://doi.org/10.3Trea347/kjp.2012.50.2.161

9. Reinert, J., Gerold, S., Scheurlen, U., Daniels, R., Wolm, M., \& Iglauer, F. (2016). 'Treatment of Tritrichomonas foetus in a cat colony with delayed release ronidazole tablets in the small intestine', Praktische Tierarzt, Berliner und Münchener tierärztliche Wochenschrift 128(9-10), pp. 362-369. 


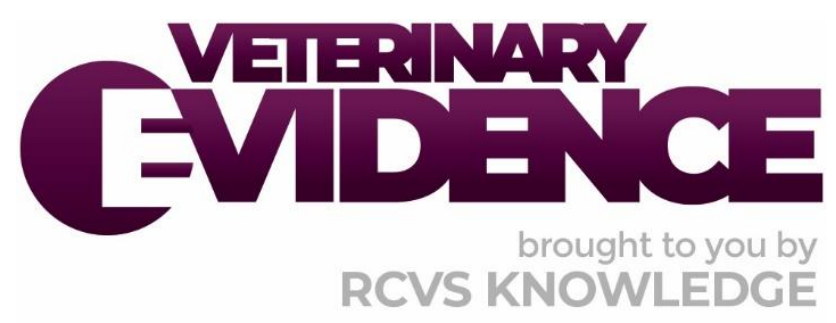

\section{Intellectual Property Rights}

Authors of Knowledge Summaries submitted to RCVS Knowledge for publication will retain copyright in their work, and will be required to grant RCVS Knowledge a non-exclusive license of the rights of copyright in the materials including but not limited to the right to publish, re-

publish, transmit, sell, distribute and otherwise use the materials in all languages and all media throughout the world, and to license or permit others to do so.

\section{Disclaimer}

Knowledge Summaries are a peer-reviewed article type which aims to answer a clinical question based on the best available current evidence. It does not override the responsibility

of the practitioner. Informed decisions should be made by considering such factors as individual clinical expertise and judgement along with patient's circumstances and owners' values. Knowledge Summaries are a resource to help inform and any opinions expressed within the Knowledge Summaries are the author's own and do not necessarily reflect the view of the RCVS Knowledge. Authors are responsible for the accuracy of the content. While the

Editor and Publisher believe that all content herein are in accord with current recommendations and practice at the time of publication, they accept no legal responsibility

for any errors or omissions, and make no warranty, express or implied, with respect to material contained within.

For further information please refer to our Terms of Use.

RCVS Knowledge is the independent charity associated with the Royal College of Veterinary Surgeons (RCVS). Our ambition is to become a global intermediary for evidence based veterinary knowledge by providing access to information that is of immediate value to practicing veterinary professionals and directly contributes to evidence based clinical decision-making.

https://www.veterinaryevidence.org/

RCVS Knowledge is a registered Charity No. 230886.

Registered as a Company limited by guarantee in England and Wales No. 598443.

Registered Office: Belgravia House, 62-64 Horseferry Road, London SW1P 2AF

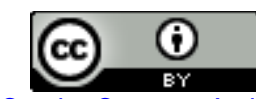

This work is licensed under a Creative Commons Attribution 4.0 International License 